Article

\title{
Corn and Rice Cultivation Affect Soil Organic and Inorganic Carbon Storage through Altering Soil Properties in Alkali Sodic Soils, Northeast of China
}

\author{
Jingjing Wang ${ }^{1,2}{ }^{\oplus}$, Jie Tang ${ }^{2}$, Zhaoyang $\mathrm{Li}^{2, *}$, Wei Yang ${ }^{2}{ }^{\oplus}$, Ping Yang ${ }^{2}$ and Yunke $\mathrm{Qu}^{2}$ \\ 1 Key Lab of Groundwater Resources and Environment, Ministry of Education, Jilin University, \\ Changchun 130012, China; jingjing16@mails.jlu.edu.cn \\ 2 College of New Energy and Environment, Jilin University, Changchun 130012, China; \\ tangjie@jlu.edu.cn (J.T.); yangwea@jlu.edu.cn (W.Y.); yangping83@jlu.edu.cn (P.Y.); \\ quyk17@mails.jlu.edu.cn (Y.Q.) \\ * Correspondence: zhaoyang@jlu.edu.cn
}

Received: 7 January 2020; Accepted: 18 February 2020; Published: 21 February 2020

\begin{abstract}
Soil organic carbon (SOC) and soil inorganic carbon (SIC) play essential roles in carbon cycling in terrestrial ecosystems; however, the effects of crop cultivation on them are still poorly understood, especially in alkali sodic soils widely distributed in semiarid regions. Alkali sodic soils from cornfields and paddies with cultivation years of 5, 15, and 25 were analyzed here to assess the response of soil properties and soil carbon pools to crop cultivation. Soil $\mathrm{pH}$ and exchangeable sodium percentages decrease in accordance with cultivation years, while enzyme activity (amylase, invertase, and catalase) shows a contrary trend. Soil $\mathrm{pH}$ and exchangeable sodium percentages are negatively correlated with SOC, but positively correlated with SIC. Redundancy analysis reveals an obvious relationship between SOC and invertase activity. The percentage of $\delta^{13} \mathrm{C}_{\mathrm{SOC}}$ found here is approximately $-24.78 \%$ o to $-22.97 \%$ o for cornfields and approximately $-26.54 \%$ o to $-23.81 \%$ o for paddies, suggesting that crop cultivation contributes to SOC sequestration and stocking, increasing with cultivation years. The percentage of $\delta^{13} \mathrm{C}_{\text {SIC }}$ found here is approximately $1.90 \%$ o to $3.73 \%$, proving that lithogenic inorganic carbon is the major SIC, where the stock decreases with increasing cultivation years. Significant total carbon stock loss is observed in cornfields, while it is preserved at $120 \mathrm{Mg} \mathrm{ha}^{-1}$ in paddies. We conclude here from the results that corn and rice cultivation reduce alkali sodic conditions in soil, thereby improving soil enzymes and favoring SOC stocking, but reducing SIC stocks.
\end{abstract}

Keywords: soil organic carbon; soil inorganic carbon; crop cultivation; ${ }^{13} \mathrm{C}$ isotope; alkali sodic soil

\section{Introduction}

Global warming is receiving more and more attention because of the series of threats it poses, like sea-level rise, land area decline, extreme climates, and food supply shortages, which challenge the sustainable development of eco-environments and social economy [1]. Greenhouse gas (GHG) emissions, including carbon dioxide $\left(\mathrm{CO}_{2}\right)$, methane $\left(\mathrm{CH}_{4}\right)$, and nitrous oxide $\left(\mathrm{N}_{2} \mathrm{O}\right)$, are responsible for global warming, owing to the greenhouse effects. Carbon (C) pools in soil are the carbon source for $\mathrm{CO}_{2}$ and $\mathrm{CH}_{4}$ production and emission. Overall, $52 \%$ of global anthropogenic $\mathrm{CH}_{4}$ is emitted from agricultural land [2]. Holding vast reserves of $C$, the $C$ variance in agricultural lands impacts the atmospheric GHG concentration and global climatic conditions. Cultivation practices regulate GHG emission and the global $C$ cycle through altering the distribution and transformation of $C$ in soil.

Soil organic carbon (SOC) is one of the main focuses of studies because of its vital role in regulating ecosystem function and greenhouse effects. SOC mainly is produced from root exudates and the 
decomposition of litter and crop residues [3-5]. The progress is susceptible to cultivation practices, which adjust soil environments, i.e., the soil $\mathrm{pH}$, soil water content, enzyme activities, and soil microbes [6-9]. Kuzyakov and Domanski (2000) noted that wheat and barley transport about $30 \%$ of the assimilated C production into soil [10]. Muller et al. (2016) reported that corn increased SOC content, especially in topsoil [11]. Rice cultivation gathers $C$ in soil, while the $C$ input in paddies is even lower (or higher) than that in upland areas [12,13]. However, few studies have taken the soil inorganic carbon (SIC) pool into account, which is the most common form of carbon in semiarid regions, representing the storage of $\sim 695-1738 \mathrm{Pg}\left(1 \mathrm{Pg}=10^{15} \mathrm{~g}\right.$ ) when assessing soil C sequestration [14,15]. SIC is classified as two central units stored in soil, namely, lithogenic inorganic carbon (LIC), inheriting from the parent material, and pedogenic inorganic carbon (PIC), resulting from the precipitation of carbonate ions. The formation of pedogenic carbonate, shown in Equations (1) and (2), can either be a source or sink of $C$ [16]. In the input or output of soil, $C$ is transformed in the process of precipitation. One unit of $\mathrm{CO}_{2}$ is consumed when a carbonate is dissolved, while, on the other hand, one unit of $\mathrm{CO}_{2}$ is released when a carbonate is redeposited. Cultivation regulates carbonate dissolution and precipitation by altering the soil $\mathrm{pH}$, soil water, ion activity $\left(\mathrm{Ca}^{2+}, \mathrm{Mg}^{2+}, \mathrm{Al}^{3+}, \mathrm{K}^{+}\right.$, and $\left.\mathrm{Fe}^{3+}\right)$, and $\mathrm{CO}_{2}$, either from the atmosphere or via microbial respiration [17-19]. Studies have reported that soil $\mathrm{pH}$ decreases or increases during rice cultivation, while increased $\mathrm{pH}$ is found for soybean cultivation $[20,21]$. Jaiyeoba (2003) noted that cation exchange capacity (CEC) declines after crop cultivation [22]. Cultivation and its management, i.e., fertilization and irrigation, governs SIC dynamics in soils through regulating the soil environment, SOC contents, and hydrological conditions [23,24]. Dong et al. (2017) noted that long-term fertilizer significantly decreased SIC content in a two-year crop rotation system, that is, winter wheat, summer corn, spring corn, and winter fallow for each two-year period [25], while Bughio et al. (2016) reported that irrigation and fertilization in a wheat-maize rotation system increased SIC content when compared with bare field [17]. Changes in the stock of SIC, induced by crop cultivation and its management, are still unclear. Thus, an accurate estimate, including both SOC and SIC, is required to assess the dynamics of soil $\mathrm{C}$ pools during cultivation in agricultural lands.

$$
\begin{gathered}
2 \mathrm{CO}_{2}+2 \mathrm{H}_{2} \mathrm{O} \leftrightarrow 2 \mathrm{HCO}_{3}^{-}+2 \mathrm{H}^{+} \\
\mathrm{Ca}^{2+}+2 \mathrm{HCO}_{3}^{-} \leftrightarrow \mathrm{CaCO}_{3}+\mathrm{H}_{2} \mathrm{O}+\mathrm{CO}_{2}
\end{gathered}
$$

Soil natural isotope analysis $\left(\delta^{13} \mathrm{C}\right)$ is used to analyze the dynamics of SOC in terrestrial ecosystems because it provides the isotope signatures of soil composition [26,27]. As is well known, the $\delta^{13} \mathrm{C}$ value of SOC for a C4 plant (Hatch-Slack pathway during photosynthesis) is approximately $-15 \%$ o to $-7 \%$, while it is approximately $-35 \%$ o to $-20 \%$ for C3 plants (Calvin cycle during photosynthesis) $[28,29]$. The $\delta^{13} \mathrm{C}$ value is a sensitive indicator to clarify the contribution of plants or crops to SOC sequestration. Chen et al. (2018) noted that, in restored mangrove forests, SOC relies on mangrove organic matter, using the $\delta^{13} \mathrm{C}$ values [30]. Chen et al. (2018) also reported that maize mulch increases SOC by $22 \%$ in topsoil [31]. Likewise, LIC and PIC are distinguished by $\delta^{13} \mathrm{C}$, which is $0 \%$ o for LIC, while for PIC it is related to the $\delta^{13} \mathrm{C}$ of SOC $[17,32]$. Jin et al. (2014) noted that the $\delta^{13} \mathrm{C}$ of SIC in grassland is lower than the forest land of the Loess Plateau, showing that grasslands produce more PIC than forest land [33]. An et al. (2019) reported that the desertification of grassland contributes to PIC formation in topsoil [34]. Therefore, soil $\delta^{13} \mathrm{C}$ analysis can be of great assistance in analyzing soil $\mathrm{C}$ pool transformations and evaluating the influence of different crops on soil C pools in agricultural lands.

Soil desertification is one of the most severe land degradation problems and has occurred on a global scale for centuries [35]. Alkali sodic soil mitigates $C$ sequestration and adjusts the global $C$ cycle through reducing microbial activity and microbial biomass, microbial community structure, and soil respiration [36-38]. Because of land degradation, alkali sodic soils are widely distributed in the northeast of China, which includes arid and semiarid regions. To ease food shortages, the local government has carried out large-scale crop cultivation in saline-alkali soils since the 1950s. Grasslands have been converted into agriculture lands, cultivating corn and rice in large amounts, 
supplying fresh organic material in soils, and increasing microbial and faunal activities [39]. However, the impacts of long-term crop cultivation on soil carbon pools in alkali sodic agricultural lands are still poorly understood. We hypothesize that crop cultivation alters soil properties and enzyme activities, affecting SOC and SIC stocks in cornfields and paddies. Thus, the objectives of the present study are to (i) analyze the alterations in soil physical and chemical properties, as well as enzyme activities in cornfields and paddies with different cultivation years, (ii) assess the response of SOC and SIC content, natural isotopes, and carbon stocks on corn and rice cultivation, and (iii) to evaluate the influence of crop cultivation on SOC and SIC, as affected by soil properties and enzyme activities.

\section{Materials and Methods}

\subsection{Site Description}

The study site was located in Songyuan, Jilin province, China (Figure 1), and is southeast of the Songnen Plain, where the area of salinized land is $1.1 \times 10^{6}$ ha [40]. The region has a semiarid and subhumid continental monsoon climate, with an annual average temperature of $5.6^{\circ} \mathrm{C}$ and an annual precipitation of $446 \mathrm{~mm}$. Soils have been cultivated regularly there since the 1950s, before which they were covered with grass, Leymus chinensis, Suaeda glauca, and Puccinellia distans being the primary forms of vegetation.

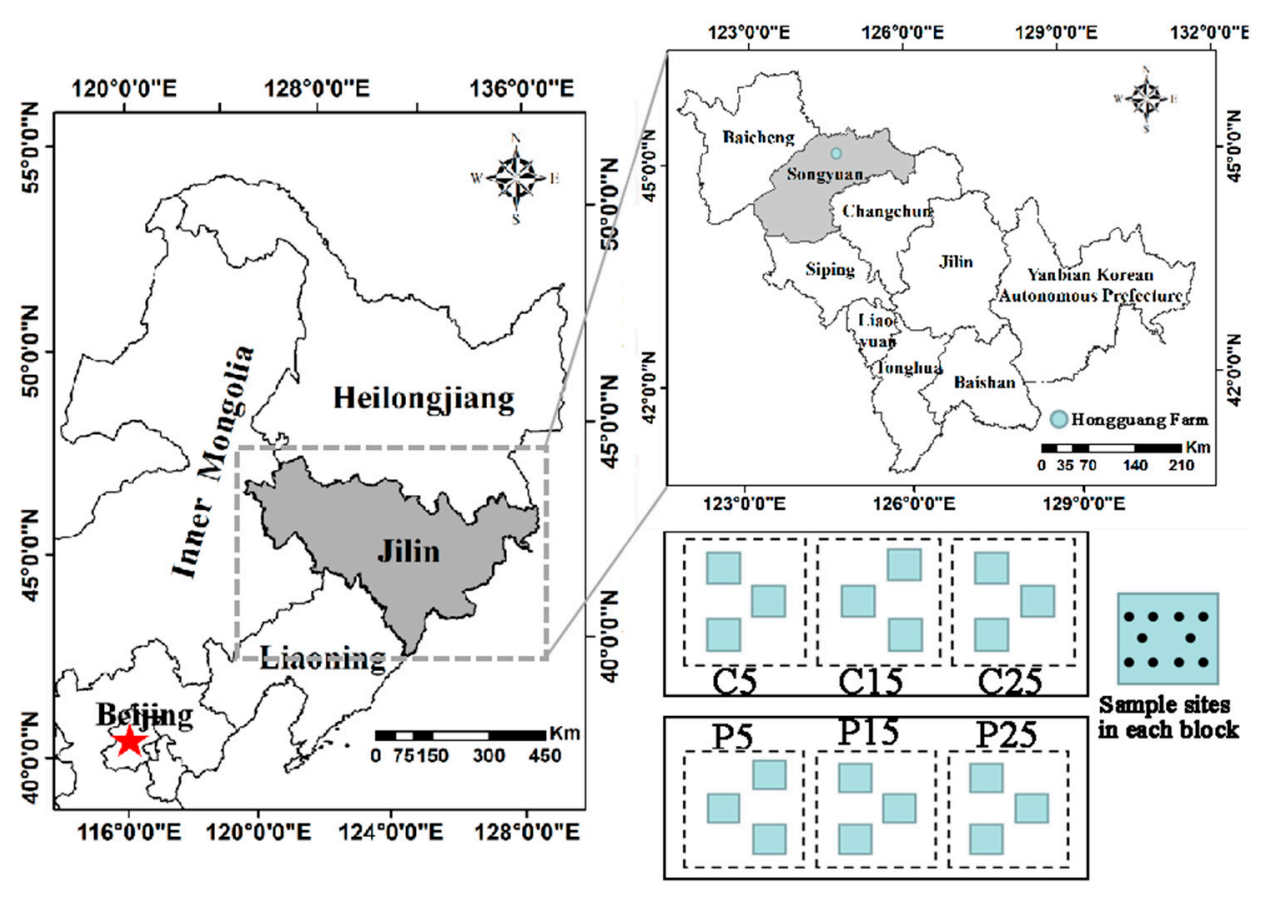

Figure 1. The location of the study area (Songyuan) in Jilin province, in the northeast of China.

Two tillage systems with one crop per year, planting in May and harvesting in October, have been investigated in the experiment. Three neighboring cornfields and three neighboring paddies were selected and studied, with areas of 1 ha $(100 \times 100 \mathrm{~m})$ per field, in Hongguang farm, Songyuan, with an elevation of $140 \mathrm{~m}$ above the mean sea level. The main landform here is plain, and the soil type is meadow soil (Eutric Vertisol [41]). The fields were covered with native degraded grass vegetation (Leymus chinensis, C3 plant) before crop cultivation, without any prior cultivation or fertilization. Here, the grass cover level was less than 50\% in 1991, when C25 and P25 were cultivated, and it has decreased steadily due to climate change, soil desertification, and human activities. Three rain-fed cornfields have been cultivated for 5 (C5), 15 (C15), and 25 years (C25), respectively, under the same conventional tillage management method. Maize seeds (Zea mays L., C4 plant) and base fertilizer were applied together by a planter machine. A blended fertilizer $\left(16 \% \mathrm{~N}, 16 \% \mathrm{P}_{2} \mathrm{O}_{5}\right.$, and $\left.16 \% \mathrm{~K}_{2} \mathrm{O}\right)$ was 
applied with an application rate of $200 \mathrm{~kg} \mathrm{ha}^{-1}$, and $180 \mathrm{~kg} \mathrm{ha}^{-1}$ urea was applied in the jointing stage. Three paddies, cultivated for 5 (P5), 15r (P15), and 25 years (P25), respectively, were under continuous irrigation, where the soil was covered with water at a depth of $5 \mathrm{~cm}$. The soils were irrigated sufficiently before planting, and then rice (Oryza sativa L., C3 plant) was planted by a planter machine. The base fertilizer, a blended fertilizer $\left(17 \% \mathrm{~N}, 18 \% \mathrm{P}_{2} \mathrm{O}_{5}\right.$, and $\left.19 \% \mathrm{~K}_{2} \mathrm{O}\right)$ with a rate of $200 \mathrm{~kg} \mathrm{ha}^{-1}$, was applied after planting, while $150 \mathrm{~kg} \mathrm{ha}^{-1}$ urea was applied in the tillering stage manually. Weed control was carried out manually with broad-spectrum herbicides. Corn and rice were harvested by machines. Crop straws were collected and processed into fertilizer, fodder, and fuel. All fields were plowed by a machine with a depth of $20 \mathrm{~cm}$ before planting. The irrigation water originates from Nen River and the groundwater depth ranges from 1.0 to $2.5 \mathrm{~m}$.

\subsection{Soil Sampling}

Soils with the depth of 0-20 cm (surface layer) and 20-40 cm (subsurface layer) were sampled on September 25, 2016. We established three blocks $(15 \times 15 \mathrm{~m})$ in each field to collect soil subsamples (ten per layer) randomly (Figure 1), using a soil auger $(7 \mathrm{~mm})$. Subsamples from the same block and layer were homogeneously mixed to generate a composite sample. A total of 36 samples were collected and sent to the lab. After removing visible roots and plant material with tweezers, the soil samples were air-dried at room temperature and sieved to $<2 \mathrm{~mm}$ for further analysis. Soil cores $\left(100 \mathrm{~cm}^{3}\right)$ in three duplicates from each layer in each field were collected for soil bulk density (BD) analysis when sampling.

\subsection{Soil Chemical Analysis}

Core samples were heated in an oven at $105^{\circ} \mathrm{C}$ for $48 \mathrm{~h}$ to identify the soil BD. A laser particle diameter analyzer (Bettersize 2000, Liaoning, China) was employed to identify the soil texture (i.e., the sand, silt, and clay proportion). Soil $\mathrm{pH}$ and electrical conductivity (EC) were tested at a ratio of 5 to 1 (water to soil). The exchangeable sodium percentage (ESP) was calculated by Equation (3) after measuring the content of exchangeable sodium $\left(\mathrm{C}_{\mathrm{Na}+}\right)$ and the cation exchange capacity (CEC) [42]. Briefly, $2.0 \mathrm{~g}$ of soil, mixed with $80 \mathrm{~mL}$ EDTA-ammonium acetate, was centrifuged for $5 \mathrm{~min}$ at 3000 $\mathrm{rpm}$. The clear liquid, with $3 \mathrm{~mL}$ aluminum sulfate solutions $(0.1 \mathrm{M})$, was diluted to test $\mathrm{C}_{\mathrm{Na}+}$ using an atomic absorption spectrophotometer. The sediment was rinsed with ethyl alcohol, distilled, and then titrated by $\mathrm{HCl}(0.05 \mathrm{M})$ to determine the CEC. A TOC analyzer (Shimadzu TOC-V SSM-5000, Japan) was employed for total carbon (TC), soil organic carbon (SOC), and SIC analysis. Briefly, two sets of soils with a mass of $50 \mathrm{mg}$ were put in sample boats separately, which were closed in the TOC analyzer. One sample for total carbon (TC) was burned at the temperature of $900{ }^{\circ} \mathrm{C}$, while the other, for inorganic carbon (IC), was burned at $200{ }^{\circ} \mathrm{C}$ immediately after adding phosphoric acid. TC and IC were computed automatically with the $\mathrm{CO}_{2}$ emitted from the samples, while $\mathrm{SOC}$ was calculated from the TC and IC.

$$
\mathrm{ESP}=\mathrm{C}_{\mathrm{Na}^{+}} / \mathrm{CEC} \times 100
$$

\subsection{Carbon Isotope Analyses}

The isotope analyses of SOC and SIC were carried out with a stable isotope mass spectrometer (Isoprime 100, Langenselbold, Germany). For the former, $5.0 \mathrm{~g}$ of soil was reacted with an overdosed $\mathrm{HCl}(1 \mathrm{M})$ solution for $24 \mathrm{~h}$ to remove SIC. They were washed with deionized water until the $\mathrm{pH}$ was less than 5 , and then dried at $40^{\circ} \mathrm{C}$. Then, the samples were combusted in an evacuated sealed quartz tube in the presence of silver foil and cupric oxide for $2 \mathrm{~h}$ at $850{ }^{\circ} \mathrm{C}$. The $\mathrm{CO}_{2}$ emitted from the reaction was extracted and analyzed with the spectrometer [43]. SIC isotope composition was determined from the $\mathrm{CO}_{2}$ gas emitted from air-dried soils reacting with $\mathrm{H}_{3} \mathrm{PO}_{4}$ for $2 \mathrm{~h}$ at $80^{\circ} \mathrm{C}$ [34]. The $\delta^{13} \mathrm{C}$ values 
of SOC $\left(\delta^{13} C_{\text {SOC }}\right)$ and SIC $\left(\delta^{13} C_{\text {SIC }}\right)$ were calculated with Equation (4) [44]. Here, Vienna Pee Dee Belemnite (VDPB) was the standard used. Three multiple samples were tested for each sample.

$$
\delta^{13} \mathrm{C}=\left(\mathrm{R}_{\mathrm{s}}+\mathrm{R}_{\mathrm{c}}\right) / \mathrm{R}_{\mathrm{c}} \times 1000 \%
$$

where $\delta^{13} \mathrm{C}$ is the natural abundance of SOC or SIC for the samples (\%o), $R_{\mathrm{s}}$ is the stable $\mathrm{C}$ isotope compositions of SOC or SIC, and $\mathrm{R}_{\mathrm{c}}$ is the isotopic composition of the standards.

\subsection{Soil Enzyme Assays}

Enzyme activities were measured following the method described by Zhang [45]. Amylase and invertase activities were determined by colorimetric assays. Briefly, $5.0 \mathrm{~g}$ of air-dried soil was reacted with a $10 \mathrm{~mL}$ substrate $\left(1 \%\right.$ starch solution) and $10 \mathrm{~mL}$ phosphate buffer at $\mathrm{pH} 5.5$ for $24 \mathrm{~h}$ at $37^{\circ} \mathrm{C}$. One $\mathrm{mL}$ of the liquid filtrated from the mixture was pipetted into a $50 \mathrm{~mL}$ flask to react with $2.0 \mathrm{~mL}$ of 3,5-dinitrosalicylic acid in boiling water for $5 \mathrm{~min}$. After cooling, it was diluted with deionized water to volume and quantified at $508 \mathrm{~nm}$ using a spectrophotometer (UV-2100, Beijing, China). For invertase, the substrate was a $15 \mathrm{~mL}$ sucrose solution (8\%), the volumes of the phosphate buffer and 3,5-dinitrosalicylic acid were $5.0 \mathrm{~mL}$ and $3.0 \mathrm{~mL}$ respectively. Controls without a substrate or soil were processed to obtain the amylase and invertase activities, expressed as $\mu \mathrm{g}$ glucose $\mathrm{g}^{-1}$ soil $^{-1}$. In order to determine the catalase activity, $2.0 \mathrm{~g}$ of air-dried soil was mixed with $40 \mathrm{~mL}$ of deionized water and reacted with $5 \mathrm{~mL}$ of $\mathrm{H}_{2} \mathrm{O}_{2}(0.3 \%)$ for $20 \mathrm{~min}$, then filtrated and titrated with $\mathrm{KMnO}_{4}\left(0.02 \mathrm{~mol} \mathrm{~L}^{-1}\right)$. Catalase activity was expressed as $\mathrm{mL} \mathrm{KMnO}_{4} \mathrm{~g}^{-1}$ soil h $\mathrm{h}^{-1}$.

\subsection{Statistical Analysis}

Total carbon stocks $\left(\mathrm{Mg} \mathrm{ha}^{-1}\right)$ were calculated as the sum of SOC and SIC densities, which were calculated using Equation (5) [46]:

$$
\mathrm{SD}=\sum_{\mathrm{i}=1}^{2} \mathrm{C}_{\mathrm{i}} \times \mathrm{BD}_{\mathrm{i}} \times \mathrm{H} \times 0.1
$$

where SD is the SOC or SIC density $\left(\mathrm{Mg} \mathrm{ha}^{-1}\right), \mathrm{C}_{\mathrm{i}}$ and $\mathrm{BD}_{\mathrm{i}}$ are the SOC or SIC concentration $\left(\mathrm{g} \mathrm{kg}^{-1}\right)$ and bulk density $\left(\mathrm{g} \mathrm{cm}^{-3}\right)$ in the layer i, respectively, and $\mathrm{H}$ is the thickness of soil (here, $\mathrm{H}=20 \mathrm{~cm}$ ).

Statistical analysis was performed with the SPSS 19.0 software package (SPSS Inc., Chicago, IL, USA). One-way analysis of variance (ANOVA) with separation of means by a least significant difference (LSD) test at $p<0.05$ was computed to assess the significant differences of soil properties, enzyme activities, and $C$ pools among fields with different cultivation years, while the t-test was employed to assess the significant differences between soil layers. The redundancy analysis (RDA) was conducted via CANOCO 4.5 (Microcomputer Power, Inc., Ithaca, NY, USA) to assess the relationships between soil carbon pools and soil physical-chemical properties and enzyme activities. SigmaPlot 12.5 (Systat Software, Inc., San Jose, CA, USA) was used for the figures.

\section{Results}

\subsection{Soil Physical-Chemical Properties}

The soil physical and chemical indicators are summarized in Table 1. Soils were alkaline for $\mathrm{pH}$ values ranging from 7.43 to 10.04 in cornfields and from 7.74 to 9.16 in paddies, despite the fact that their values were reasonably high in the subsurface layer. The EC in cornfields was $0.18-0.45 \mathrm{~ms} \mathrm{~cm}^{-1}$, and the largest value appeared in C5. They ranged from 0.22 to $0.46 \mathrm{~ms} \mathrm{~cm}^{-1}$ in paddies, where relatively large values appeared in the surface layer. Soils in the study area were slightly sodic, with ESP $<15 \%$ indicating strongly sodic soil, with ESP $=24.32 \%$ in C5. The texture of the cornfield and paddy was of silt loam soil, although the silt content was higher in paddies compared with the cornfields. The soil 
bulk density ranged from 1.27 to $1.41 \mathrm{~g} \mathrm{~cm}^{-3}$ in cornfields, while it ranged from 1.30 to $1.66 \mathrm{~g} \mathrm{~cm}^{-3}$ in paddies, where larger values appeared in the subsurface layer.

Table 1. Soil physical and chemical properties $(n=3)$.

\begin{tabular}{|c|c|c|c|c|c|c|c|c|}
\hline & & $\mathrm{pH}$ & $\begin{array}{c}E C \\
\left(\mathrm{~ms} \mathrm{~cm}^{-1}\right)\end{array}$ & $\begin{array}{l}\text { ESP } \\
(\%)\end{array}$ & $\begin{array}{c}\text { Sand } \\
(\%)\end{array}$ & $\begin{array}{l}\text { Silt } \\
(\%)\end{array}$ & $\begin{array}{l}\text { Clay } \\
(\%)\end{array}$ & $\begin{array}{c}\text { BD } \\
\left(\mathrm{g} \mathrm{cm}^{-3}\right)\end{array}$ \\
\hline \multirow[t]{2}{*}{$\mathrm{C} 5$} & $0-20 \mathrm{~cm}$ & $\begin{array}{c}9.04 \pm 0.26 \\
\mathrm{Ab}\end{array}$ & $\begin{array}{c}0.42 \pm 0.03 \\
\mathrm{Aa}\end{array}$ & $\begin{array}{c}17.51 \pm 1.14 \\
\mathrm{Ab}\end{array}$ & $\begin{array}{c}37.29 \pm 2.58 \\
\mathrm{Aa}\end{array}$ & $\begin{array}{c}58.98 \pm 1.18 \\
\mathrm{Aa}\end{array}$ & $\begin{array}{c}4.39 \pm 0.41 \\
\mathrm{Ba}\end{array}$ & $\begin{array}{c}1.30 \pm 0.33 \\
\mathrm{Aa}\end{array}$ \\
\hline & $20-40 \mathrm{~cm}$ & $\begin{array}{c}10.04 \pm 0.05 \\
\mathrm{Aa}\end{array}$ & $\begin{array}{c}0.46 \pm 0.05 \\
\mathrm{Aa}\end{array}$ & $\begin{array}{c}24.32 \pm 2.49 \\
\mathrm{Aa}\end{array}$ & $\begin{array}{c}36.63 \pm 1.54 \\
\mathrm{Aa}\end{array}$ & $\begin{array}{c}57.98 \pm 2.48 \\
\mathrm{Bb}\end{array}$ & $\begin{array}{c}4.74 \pm 0.12 \\
\mathrm{Ca}\end{array}$ & $\begin{array}{c}1.35 \pm 0.11 \\
\mathrm{Aa}\end{array}$ \\
\hline \multirow[t]{2}{*}{ C15 } & $0-20 \mathrm{~cm}$ & $\begin{array}{c}8.07 \pm 0.07 \\
\mathrm{Bb}\end{array}$ & $\begin{array}{c}0.29 \pm 0.03 \\
\mathrm{Bb}\end{array}$ & $\begin{array}{c}7.13 \pm 0.16 \\
\mathrm{Bb}\end{array}$ & $\begin{array}{c}36.18 \pm 1.87 \\
\mathrm{Aa}\end{array}$ & $\begin{array}{c}59.68 \pm 1.69 \\
\mathrm{Ab}\end{array}$ & $\begin{array}{c}4.14 \pm 0.21 \\
\mathrm{Bb}\end{array}$ & $\begin{array}{c}1.34 \pm 0.09 \\
\mathrm{Aa}\end{array}$ \\
\hline & $20-40 \mathrm{~cm}$ & $\begin{array}{c}8.92 \pm 0.32 \\
\mathrm{ABa}\end{array}$ & $\begin{array}{c}0.45 \pm 0.01 \\
\text { Аа }\end{array}$ & $\begin{array}{c}14.38 \pm 1.02 \\
\mathrm{Ba}\end{array}$ & $\begin{array}{c}29.12 \pm 0.45 \\
\mathrm{Bb}\end{array}$ & $\begin{array}{c}63.69 \pm 0.48 \\
\mathrm{Aa}\end{array}$ & $\begin{array}{c}7.19 \pm 0.31 \\
\mathrm{Aa}\end{array}$ & $\begin{array}{c}1.39 \pm 0.13 \\
\text { Аа }\end{array}$ \\
\hline \multirow[t]{2}{*}{$\mathrm{C} 25$} & $0-20 \mathrm{~cm}$ & $\begin{array}{c}7.43 \pm 0.02 \\
\mathrm{Cb}\end{array}$ & $\begin{array}{c}0.18 \pm 0.01 \\
\mathrm{Cb}\end{array}$ & $\begin{array}{c}6.12 \pm 0.34 \\
\mathrm{Bb}\end{array}$ & $\begin{array}{c}33.46 \pm 1.47 \\
\mathrm{Aa}\end{array}$ & $\begin{array}{c}61.19 \pm 1.36 \\
\mathrm{Ab}\end{array}$ & $\begin{array}{c}5.35 \pm 0.12 \\
\mathrm{Aa}\end{array}$ & $\begin{array}{c}1.27 \pm 0.22 \\
\mathrm{Ab}\end{array}$ \\
\hline & $20-40 \mathrm{~cm}$ & $\begin{array}{c}8.86 \pm 0.10 \\
\mathrm{Ba}\end{array}$ & $\begin{array}{c}0.30 \pm 0.04 \\
\mathrm{Ba}\end{array}$ & $\begin{array}{c}7.72 \pm 0.72 \\
\mathrm{Ca}\end{array}$ & $\begin{array}{c}29.32 \pm 0.97 \\
\mathrm{Bb}\end{array}$ & $\begin{array}{c}65.13 \pm 0.87 \\
\mathrm{Aa}\end{array}$ & $\begin{array}{c}5.55 \pm 0.12 \\
\mathrm{Ba}\end{array}$ & $\begin{array}{c}1.41 \pm 0.32 \\
\mathrm{Aa}\end{array}$ \\
\hline \multirow[t]{2}{*}{ P5 } & $0-20 \mathrm{~cm}$ & $\begin{array}{c}8.84 \pm 0.01 \\
\mathrm{Ab}\end{array}$ & $\begin{array}{c}0.46 \pm 0.01 \\
\text { Аa }\end{array}$ & $\begin{array}{c}12.4 \pm 1.08 \\
\mathrm{Ab}\end{array}$ & $\begin{array}{c}20.43 \pm 1.20 \\
\mathrm{Aa}\end{array}$ & $\begin{array}{c}69.74 \pm 1.37 \\
\mathrm{Ab}\end{array}$ & $\begin{array}{c}9.83 \pm 0.51 \\
\mathrm{Aa}\end{array}$ & $\begin{array}{c}1.30 \pm 0.11 \\
\mathrm{Cb}\end{array}$ \\
\hline & $20-40 \mathrm{~cm}$ & $\begin{array}{c}9.16 \pm 0.07 \\
\mathrm{Aa}\end{array}$ & $\begin{array}{c}0.31 \pm 0.03 \\
\mathrm{Ab}\end{array}$ & $\begin{array}{c}14.88 \pm 0.32 \\
\mathrm{Aa}\end{array}$ & $\begin{array}{c}9.18 \pm 1.98 \\
\mathrm{ABb}\end{array}$ & $\begin{array}{c}81.52 \pm 2.34 \\
\mathrm{Ba}\end{array}$ & $\begin{array}{c}9.31 \pm 0.36 \\
\mathrm{Aa}\end{array}$ & $\begin{array}{c}1.38 \pm 0.46 \\
\mathrm{Ca}\end{array}$ \\
\hline \multirow[t]{2}{*}{ P15 } & $0-20 \mathrm{~cm}$ & $\begin{array}{c}8.63 \pm 0.09 \\
\mathrm{Ab}\end{array}$ & $\begin{array}{c}0.42 \pm 0.01 \\
\mathrm{Ba}\end{array}$ & $\begin{array}{c}10.64 \pm 0.55 \\
\mathrm{Ab}\end{array}$ & $\begin{array}{c}13.99 \pm 4.92 \\
\mathrm{Aa}\end{array}$ & $\begin{array}{c}75.87 \pm 4.43 \\
\mathrm{Aa}\end{array}$ & $\begin{array}{c}10.15 \pm 0.49 \\
\mathrm{Aa}\end{array}$ & $\begin{array}{c}1.54 \pm 0.12 \\
\mathrm{Ab}\end{array}$ \\
\hline & $20-40 \mathrm{~cm}$ & $\begin{array}{c}8.80 \pm 0.04 \\
\mathrm{Ba}\end{array}$ & $\begin{array}{c}0.26 \pm 0.01 \\
\mathrm{Bb}\end{array}$ & $\begin{array}{c}13.59 \pm 0.41 \\
\mathrm{Ba}\end{array}$ & $\begin{array}{c}16.17 \pm 3.46 \\
\mathrm{Aa}\end{array}$ & $\begin{array}{c}73.38 \pm 2.96 \\
\text { Аа }\end{array}$ & $\begin{array}{c}10.46 \pm 0.50 \\
\mathrm{Aa}\end{array}$ & $\begin{array}{c}1.66 \pm 0.15 \\
\mathrm{Aa}\end{array}$ \\
\hline \multirow[t]{2}{*}{ P25 } & $0-20 \mathrm{~cm}$ & $\begin{array}{c}7.74 \pm 0.15 \\
\mathrm{Ba}\end{array}$ & $\begin{array}{c}0.27 \pm 0.01 \\
\mathrm{Ca}\end{array}$ & $\begin{array}{c}5.87 \pm 0.41 \\
\mathrm{Bb}\end{array}$ & $\begin{array}{c}12.78 \pm 3.48 \\
\mathrm{Aa}\end{array}$ & $\begin{array}{c}76.55 \pm 2.93 \\
\mathrm{Ab}\end{array}$ & $\begin{array}{c}10.68 \pm 0.71 \\
\mathrm{Aa}\end{array}$ & $\begin{array}{c}1.38 \pm 0.31 \\
\mathrm{Bb}\end{array}$ \\
\hline & $20-40 \mathrm{~cm}$ & $\begin{array}{c}8.26 \pm 0.06 \\
\mathrm{Ca}\end{array}$ & $\begin{array}{c}0.22 \pm 0.02 \\
\mathrm{Bb}\end{array}$ & $\begin{array}{c}7.11 \pm 0.30 \\
\mathrm{Ca}\end{array}$ & $\begin{array}{c}6.00 \pm 0.47 \\
\mathrm{Ba}\end{array}$ & $\begin{array}{c}84.46 \pm 2.46 \\
\mathrm{Ba}\end{array}$ & $\begin{array}{c}9.55 \pm 1.99 \\
\mathrm{Aa}\end{array}$ & $\begin{array}{c}1.50 \pm 0.25 \\
\mathrm{Ba}\end{array}$ \\
\hline
\end{tabular}

Mean \pm standard errors. EC: Electrical conductivity; ESP: Exchangeable sodium percentage; BD: Bulk density; C: Cornfield; P: Paddy. Capital letters indicate the significance among plots with different cultivation years, while lowercase letters indicate the difference between layers $(p<0.05)$.

\subsection{Soil Enzyme Activities}

In cornfields and paddies, enzyme activities in the surface layers were always larger than in the subsurface layers, and larger values were detected in longer cultivation years. Amylase activities in the surface layer were 1.61 and 1.64 times larger than in subsurface layers of the cornfields and paddies, respectively. Amylase activities in C25 (58.05 $\mu$ g glucose $\left.\mathrm{g}^{-1} \mathrm{~h}^{-1}\right)$ and P25 $\left(80.87 \mu \mathrm{g}\right.$ glucose $\left.\mathrm{g}^{-1} \mathrm{~h}^{-1}\right)$ were significantly higher than others. Amylase activities in paddies were always higher than cornfields with the same cultivation year. Invertase activities ranged from 18.27 to $279.44 \mu \mathrm{g}$ glucose $\mathrm{g}^{-1} \mathrm{~h}^{-1}$ in cornfields and 73.35 to $462.14 \mu \mathrm{g}$ glucose $\mathrm{g}^{-1} \mathrm{~h}^{-1}$ in paddies. Differing from amylase, the activities of invertase in the surface of C5 (158.62 $\mu$ g glucose $\left.\mathrm{g}^{-1} \mathrm{~h}^{-1}\right)$ and C15 $\left(227.47 \mu \mathrm{g}\right.$ glucose $\left.\mathrm{g}^{-1} \mathrm{~h}^{-1}\right)$ were lower than in P5 (134.04 $\mu$ g glucose $\left.\mathrm{g}^{-1} \mathrm{~h}^{-1}\right)$ and P15 $\left(235.28 \mu \mathrm{g}\right.$ glucose $\left.\mathrm{g}^{-1} \mathrm{~h}^{-1}\right)$. Catalase activities in the cornfields and paddies had mean values of $4.64 \mathrm{~mL} \mathrm{KMnO}_{4} \mathrm{~g}^{-1}$ and $5.65 \mathrm{~mL} \mathrm{KMnO}_{4} \mathrm{~g}^{-1}$, respectively. Higher catalase activities were observed in paddies than in cornfields, except for the subsurface layer of P5 (2.31 $\left.\mathrm{mL} \mathrm{KMnO}_{4} \mathrm{~g}^{-1}\right)$.

\subsection{Soil Carbon Distribution}

SOC decreased with increasing soil depth in both the cornfields and paddies (Figure 2a). It was approximately 1.3 times larger than subsurface soil, varying from 9.78 to $11.83 \mathrm{~g} \mathrm{~kg}^{-1}$ in the surface layer and from 7.77 to $9.46 \mathrm{~g} \mathrm{~kg}^{-1}$ in the subsurface layer in cornfields. SOC increased with cultivation years, such that SOC in P25 (C15) was the largest, while the least appeared in P5 (C5). Larger SOC contents were always observed in paddies rather than cornfields, i.e., they were $11.67 \mathrm{~g} \mathrm{~kg}^{-1}$ and $12.67 \mathrm{~g} \mathrm{~kg}^{-1}$ in the surface layer of C15 and P15, respectively. 


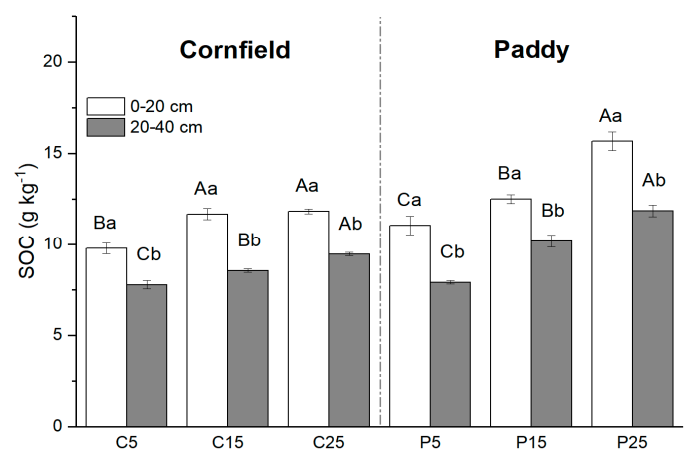

(a)

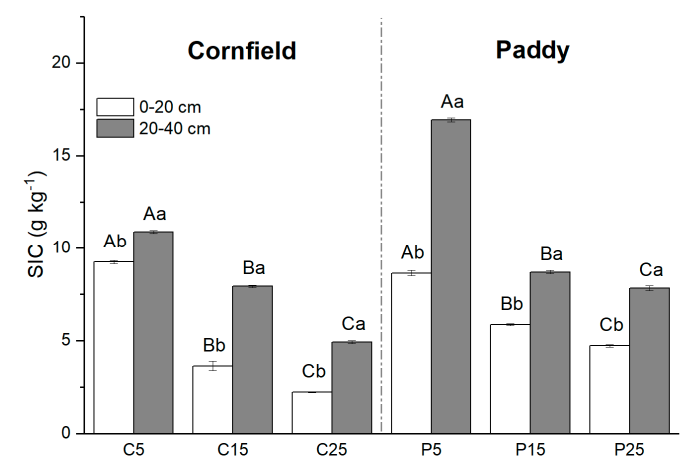

(b)

Figure 2. Soil carbon distribution in cornfields and paddies with different cultivation years: (a) Soil organic carbon (SOC); (b) soil inorganic carbon (SIC). Capital letters indicate the significance among plots with different cultivation years, while lowercase letters indicate the difference between layers $(p<$ 0.05).

The vertical distribution of SIC increased with soil depth, with an opposite trend of SOC (Figure 2b). Larger SIC content was observed in subsurface soil, ranging from 4.72 to $10.88 \mathrm{~g} \mathrm{~kg}^{-1}$, and 7.81 to $16.92 \mathrm{~g} \mathrm{~kg}^{-1}$ in cornfields and paddies, respectively. SIC declined with increasing cultivation years. SIC in the surface layer of C25 $\left(9.23 \mathrm{~g} \mathrm{~kg}^{-1}\right)$ was more than four times that of C5 $\left(2.23 \mathrm{~g} \mathrm{~kg}^{-1}\right)$. Paddies had larger SIC content when compared to cornfields of the same cultivation year.

\subsection{Soil Carbon Stocks}

SOC and SIC density changed with increasing cultivation years in both cornfields and paddies, affecting the soil carbon stocks. The total organic carbon stock at a depth of $40 \mathrm{~cm}$ was $76.14 \mathrm{Mg} \mathrm{ha}^{-1}$ in cornfields after 25 years of cultivation, while it was maintained at $120 \mathrm{Mg} \mathrm{ha}^{-1}$ in paddies (Figure 3). SIC stocks contributed to nearly half of total carbon stocks in C5 and P5, but they declined to $25.59 \%$ and $33.92 \%$ in C25 and P25, respectively. The SIC stocks were lower, up to $33.87 \mathrm{Mg} \mathrm{ha}^{-1}$ and $28.76 \mathrm{Mg} \mathrm{ha}^{-1}$ in the cornfields and paddies after 20 years of cultivation (from 5 to 25 years), respectively. SOC stocks showed an opposite trend with SIC for the stocks in C25 and P25, which were 1.22 and 1.56 times that of $\mathrm{C} 5$ and $\mathrm{P} 5$, respectively.

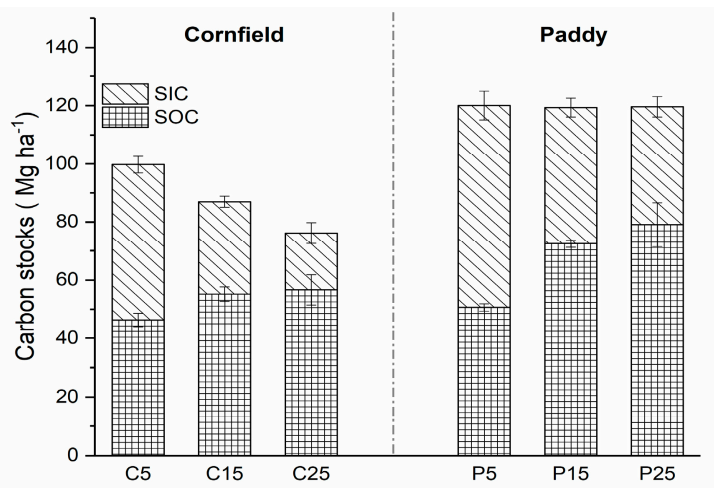

Figure 3. Carbon stocks in cornfields and paddies $(0-40 \mathrm{~cm})$ with different cultivation years.

\subsection{The $\delta^{13} \mathrm{C}$ Values of SOC and SIC}

The $\delta^{13} \mathrm{C}$ of SOC in cornfields, with a mean value of $-23.88 \%$, was higher than in paddies $(-25.57 \%$ ) (Figure 4). Higher values were observed in the surface layer as compared with the subsurface soils in cornfields, varying from $-24.40 \%$ o to $-22.97 \%$. The $\delta^{13} \mathrm{C}_{\mathrm{SOC}}$ value in C25 was 
the highest, followed by $\mathrm{C} 15$ and $\mathrm{C} 5$. A similar trend was detected in paddies, where the $\delta^{13} \mathrm{C}_{\mathrm{SOC}}$ values were in the range of $\mathrm{P} 25, \mathrm{P} 15$, and $\mathrm{P} 5$, although the values in the subsurface were larger than that in the surface soil. The $\delta^{13} \mathrm{C}$ of SIC ranged from approximately $1.90 \%$ o to $4.07 \%$ o in cornfields, where small values appeared in the surface layer (Figure 5). $\mathrm{C} 5$ had significantly higher $\delta^{13} \mathrm{C}_{\text {SIC }}$ values (3.79\%o and $4.47 \%$ o) than C15 (3.25\%o and 3.90\%o) and C25 (1.90\%o and 3.73\%o). The $\delta^{13} \mathrm{C}_{\text {SIC }}$ value was approximately $2.01 \%$ o to $3.29 \%$ in paddies, where larger values appeared in the surface layer. The $\delta^{13} \mathrm{C}_{\text {SIC }}$ in the surface layer of P25 was $2.29 \%$, which was significantly lower than other paddies.

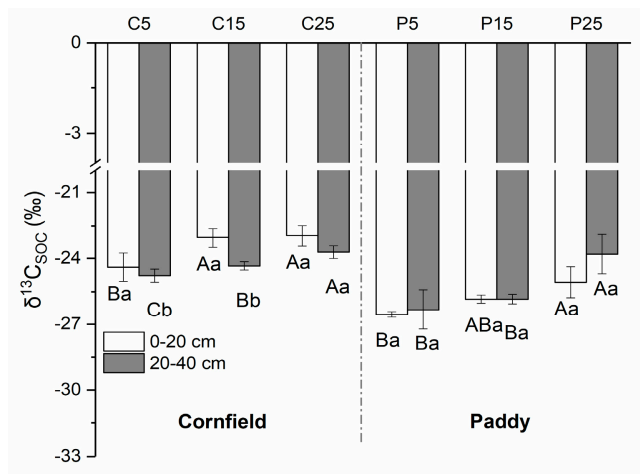

Figure 4. The natural abundance of SOC isotopes $\left(\delta^{13} \mathrm{C}_{\mathrm{SOC}}\right)$ in cornfields $(\mathrm{C})$ and paddies $(\mathrm{P})$. Capital letters indicate the significance among plots with different cultivation years, while lowercase letters indicate the difference between layers $(p<0.05)$.

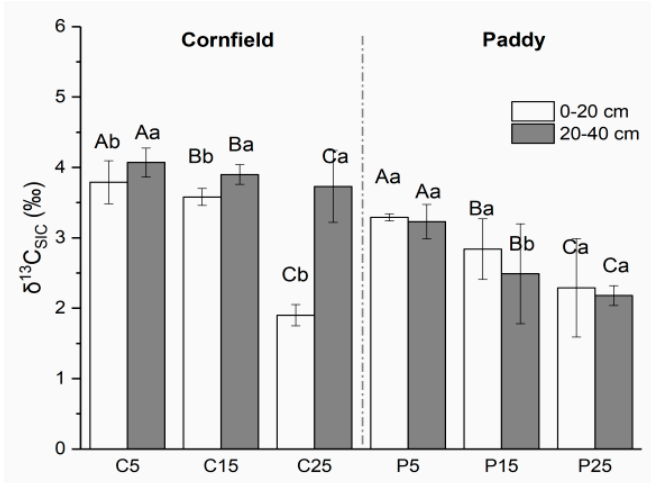

Figure 5. The natural abundance of SIC isotopes $\left(\delta^{13} \mathrm{C}_{\text {SIC }}\right)$ in cornfields $(\mathrm{C})$ and paddies (P). Capital letters indicate the significance among plots with different cultivation years, while lowercase letters indicate the difference between layers $(p<0.05)$.

\subsection{Redundancy Analysis between Soil Properties, Enzyme Activities, and Soil Carbon Pools}

The relationship between soil properties, including the physical, chemical, and biological properties (enzyme activities), and soil carbon pools, was analyzed by RDA (Figure 6). The first two component axes explain approximately $89.43 \%$ to $91.97 \%$ and $6.35 \%$ to $8.61 \%$ of the variance of soil carbon pools, respectively. Soil $\mathrm{pH}, \mathrm{EC}, \mathrm{ESP}$, invertase, catalase, and amylase played a bigger role than the soil physical properties, i.e., the $\mathrm{BD}$, sand, silt, and clay content, in terms of explaining soil carbon pools. Soil organic carbon pools, SOC, $\delta^{13} \mathrm{C}_{\mathrm{SOC}}$, and SOC density, were positively correlated with enzyme activities, i.e., invertase, catalase, and amylase, while they showed significantly negative correlations with $\mathrm{pH}, \mathrm{ESP}$, and EC in the cornfields (Figure 6a). SIC was positively correlated with $\mathrm{pH}$, ESP, and EC. In the paddies, SOC was significantly positively correlated with EC and invertase and was negatively correlated with $\mathrm{pH}$ and ESP, which was contrary to SIC (Figure 6b). Soil amylase, catalase, and invertase activities showed negative correlations with soil $\mathrm{pH}$ and ESP in both fields. 


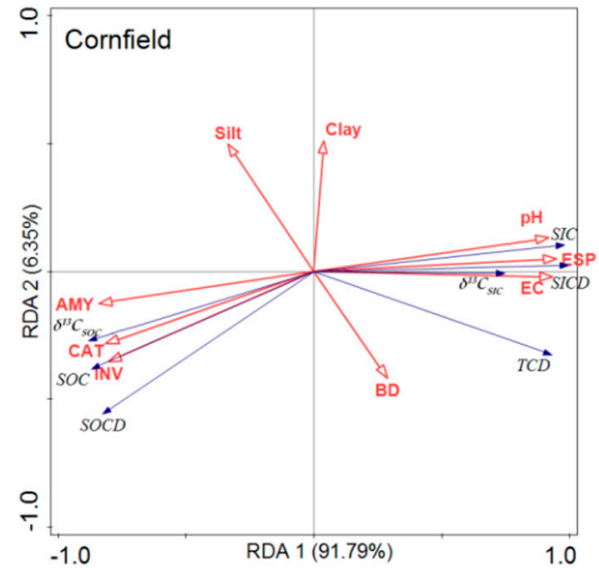

(a)

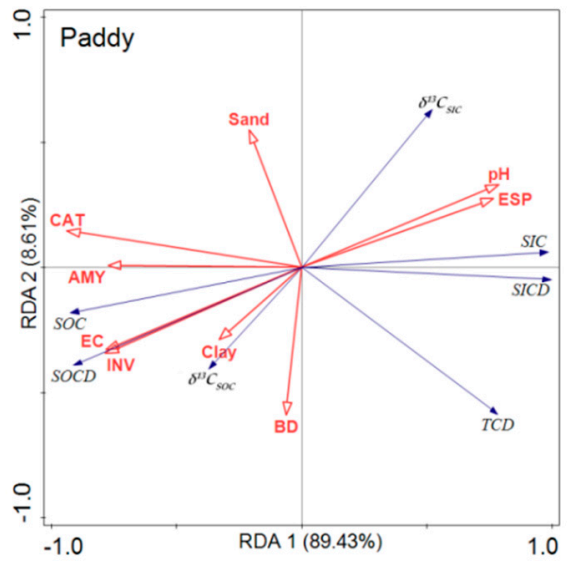

(b)

Figure 6. Redundancy analyses of soil carbon pools, soil properties, and soil enzyme activities. (a) Cornfield. (b) Paddy. AMY, CAT, and INV represent the activities of amylase, catalase, and invertase, respectively. $\mathrm{BD}, \mathrm{EC}$, and ESP represent the bulk density, electrical conductivity, and exchangeable sodium percentage, respectively. SOCD, SICD, and TCD represent the stock of SOC, SIC, and TC, respectively.

\section{Discussion}

\subsection{Effects of Crop Cultivation on Soil Properties and Enzyme Activities}

Crop cultivation affects soil physical and chemical properties, as well as enzyme activities in both cornfields and paddies, through altering the soil structure, aggregation, porosity, strength, and infiltration with tillage practices [47]. Continuous irrigation and fertilization induces a reduction in soil $\mathrm{pH}$ [48]. In our study, the $\mathrm{pH}$ in the surface soil was significantly lower than in the subsurface layer, and a lower soil $\mathrm{pH}$ was observed in fields with longer cultivation years (Table 1). Consistent with Luo et al. (2017), maize cultivation in the Songnen Plain significantly improved soil quality [49], where EC and ESP decreased with cultivation years for long-term cultivation, and fertilization induced a reduction of $\mathrm{Na}^{+}, \mathrm{Mg}^{2+}$, and soil salinity [50]. Awe et al. (2020) suggested that crop cultivation reduces soil BD [51]; however, it was only observed in cornfields that BD in C25 was lower than C5 (Table 1). In paddies, soil BD and clay content increased with increasing cultivation years, which was related to the continuous flood irrigation [52].

Soil enzymes, mainly derived from soil microorganisms, crops, and root exudates [53], were sensitive to crop cultivation. They were active in the surface soil and their activities increased with cultivation years (Table 2). Long-term $\mathrm{N}$ fertilization increased enzyme activities associated with hydrolytic $\mathrm{C}$ for sufficient $\mathrm{N}$ supply in both the cornfields and paddies, not only directly stimulating soil microbes to produce more enzymes, but also favoring corn and rice production to increase root exudation [54]. The soil physical and chemical properties, altered by corn and rice cultivation, affected soil enzyme activities. Invertase, amylase, and catalase activities were negatively correlated with soil $\mathrm{pH}$ and ESP in our study (Figure 6), because high soil $\mathrm{pH}$ and ESP restricted the growth and development of corn and rice, limiting the metabolic process of soil microbes, and affecting the release of root exudates, limiting soil enzyme activities [55]. The soil $\mathrm{C}$ and $\mathrm{N}$ contents were closely related to soil enzyme activities [56] and sufficient SOC content, as well as long-term fertilization, which can explain the higher enzyme activities observed in fields with longer cultivation years in our study (Figure 2a). 
Table 2. Soil enzyme activities under cornfields (C) and paddies (P) with depths of 0-20 cm and $20-40 \mathrm{~cm}$.

\begin{tabular}{|c|c|c|c|c|}
\hline & & $\begin{array}{c}\text { Amylase } \\
\left(\mu \mathrm{g} \text { glucose } \mathrm{g}^{-1} \mathrm{~h}^{-1}\right)\end{array}$ & $\begin{array}{c}\text { Invertase } \\
\left(\mu \mathrm{g} \text { glucose } \mathrm{g}^{-1} \mathrm{~h}^{-1}\right)\end{array}$ & $\begin{array}{c}\text { Catalase } \\
\left(\mathrm{mL} \mathrm{KMnO}_{4} \mathrm{~g}^{-1} \mathrm{~h}^{-1}\right)\end{array}$ \\
\hline \multirow{2}{*}{ C5 } & $0-20 \mathrm{~cm}$ & $39.97 \pm 1.02 \mathrm{Ba}^{1}$ & $158.62 \pm 2.53 \mathrm{Ca}$ & $4.84 \pm 0.02 \mathrm{Ba}$ \\
\hline & $20-40 \mathrm{~cm}$ & $19.01 \pm 0.54 \mathrm{Ab}$ & $18.27 \pm 1.02 \mathrm{Cb}$ & $3.58 \pm 0.01 \mathrm{Cb}$ \\
\hline \multirow{2}{*}{$\mathrm{C} 15$} & $0-20 \mathrm{~cm}$ & $40.00 \pm 1.61 \mathrm{Ba}$ & $227.47 \pm 7.38 \mathrm{Ba}$ & $4.96 \pm 0.2 \mathrm{Ba}$ \\
\hline & $20-40 \mathrm{~cm}$ & $31.87 \pm 0.17 \mathrm{Ca}$ & $61.91 \pm 4.05 \mathrm{Bb}$ & $4.23 \pm 0.11 \mathrm{Bb}$ \\
\hline \multirow{2}{*}{ C25 } & $0-20 \mathrm{~cm}$ & $58.05 \pm 4.06 \mathrm{Aa}$ & $279.44 \pm 13.43 \mathrm{Aa}$ & $5.61 \pm 0.23 \mathrm{Aa}$ \\
\hline & $20-40 \mathrm{~cm}$ & $39.42 \pm 0.32 \mathrm{Bb}$ & $83.29 \pm 2.28 \mathrm{Ab}$ & $4.59 \pm 0.16 \mathrm{Ab}$ \\
\hline \multirow{2}{*}{ P5 } & $0-20 \mathrm{~cm}$ & $58.90 \pm 0.64 \mathrm{Ba}$ & $134.04 \pm 19.05 \mathrm{Ca}$ & $6.31 \pm 0.17 \mathrm{Ba}$ \\
\hline & $20-40 \mathrm{~cm}$ & $41.85 \pm 2.92 \mathrm{Ab}$ & $73.35 \pm 3.40 \mathrm{Cb}$ & $2.31 \pm 0.06 \mathrm{Cb}$ \\
\hline \multirow{2}{*}{ P15 } & $0-20 \mathrm{~cm}$ & $75.74 \pm 5.28 \mathrm{Aa}$ & $235.28 \pm 14.63 \mathrm{Ba}$ & $6.46 \pm 1.93 \mathrm{Ba}$ \\
\hline & $20-40 \mathrm{~cm}$ & $43.47 \pm 3.02 \mathrm{Ab}$ & $114.75 \pm 7.82 \mathrm{Bb}$ & $4.24 \pm 0.12 \mathrm{Bb}$ \\
\hline \multirow{2}{*}{ P25 } & $0-20 \mathrm{~cm}$ & $80.87 \pm 0.41 \mathrm{Aa}$ & $462.14 \pm 28.92 \mathrm{Aa}$ & $7.58 \pm 0.13 \mathrm{Aa}$ \\
\hline & $20-40 \mathrm{~cm}$ & $45.76 \pm 0.47 \mathrm{Ab}$ & $276.29 \pm 14.63 \mathrm{Ab}$ & $6.98 \pm 0.46 \mathrm{Aa}$ \\
\hline
\end{tabular}

${ }^{1}$ Capital letters indicate the significance among plots with different cultivation years, while lowercase letters indicate the difference between layers $(p<0.05)$.

\subsection{Effects of Crop Cultivation on SOC}

Crop cultivation affected the vertical distribution of SOC in our study. SOC in the surface soil was significantly higher than that in the subsurface layer, agreeing with previous studies $[11,17,57]$. The $\delta^{13} \mathrm{C}$ values of SOC were closely related to the $\delta^{13} \mathrm{C}$ values of the plant material it originated from. In our study, the mean values of $\delta^{13} \mathrm{C}_{\mathrm{SOC}}$ in the surface layer were $-23.48 \%$ o for the cornfields and $-25.82 \%$ or for the paddies (Figure 4), which were closer to the $\delta^{13} \mathrm{C}_{\mathrm{SOC}}$ value of corn (approximately $-15 \%$ o to $-17 \%$ ) and rice (approximately $-35 \%$ o to $-20 \%$ o), inferring that crop cultivation performed sound effects on SOC sequestration and the fixation of surface soil. The crops fixed atmospheric carbon into soils by photosynthesis, which transforms $\mathrm{CO}_{2}$ from the air and releases it to the soil through the huge living root systems, which were well developed in the surface layer [58,59]. Fertilizer application in soil facilitates crop growth, thus improving $C$ accumulation in the surface layer [17]. As reported by Jian et al. (2016) and Lu et al. (2011), N fertilization increases SOC content [54,60]. Moreover, the decayed roots also attribute to the SOC in soil [27,61-64].

SOC increased with cultivation years, and a larger value of $\delta^{13} \mathrm{C}_{\mathrm{SOC}}$ appeared in fields with longer cultivation years in both layers (Figures $2 \mathrm{a}$ and 4 ), suggesting that long-term crop cultivation is valuable for SOC sequestration in the studied alkali sodic soils. Long-term fertilization, irrigation, and the decomposition of litters and roots increased SOC content, and the infiltration and transformation of soil particle fractions, as well as dissolved OC, increased the SOC content in subsurface soils $[65,66]$. The soil environment was altered by continual cultivation practice, contributing to SOC storage. Soil $\mathrm{pH}$ was the most sensitive indicator that regulated the SOC cycle and sequestration for the influence on crop growth, soil microorganisms, and enzyme activities [67-69]. The optimum $\mathrm{pH}$ for bacteria is 6.5-8, and 5-6 for fungi $[70,71]$. The intense alkali conditions, i.e., soil $\mathrm{pH}$ in $\mathrm{C} 5$ and $\mathrm{P} 5$, was 9.04 and 8.84 , limited soil microbial activities, as well as the humification progress of root and litters, preventing the input and accumulation of SOC [72]. ESP significantly correlated with soil $\mathrm{pH}$, showing a negative correlation with SOC in our study (Figure 6), implying that lower ESP conditions favor SOC and its storage. Wang et al. (2019) noted that SOC increased with cultivation years for native grassland converted into cropland, because decreasing soil salinity alleviates salt stress, as well as $\mathrm{N}$ fertilization, which is beneficial to plant growth and SOC accumulation [73]. Du et al. (2019) reported that grassland ecosystems have higher $C$ losses than farmland when following desertification [74], which could also attribute to the SOC increment with increasing cultivation years. Soil desertification in the Songnen Plain has decreased the area of grassland, as well as grass vegetation coverage, resulting in a lower input of above- and below-ground biomass, reducing the SOC stock and increasing soil erosion from wind and water [75]. For instance, SOC losses induced by the 20-year coverage of degraded grasses in 
C5 (and P5) were related to the low SOC stocks as compared with C25 (and P25) (Figure 3). Soil enzymes participate in the metabolism of organic matter, catalyze biochemical processes, and affect soil nutrient accumulation and mineralization [76,77]. In the present study, invertase had significant impacts on SOC content in both the cornfields and paddies (Figure 6). Some studies have argued that a high clay content stabilizes SOC physically by forming organo-mineral complexes and micro-aggregates to protect SOC from decay $[28,78]$, whereas the correlation between SOC and clay was only detected in paddies here (Figure 6).

\subsection{Effects of Crop Cultivation on SIC}

Our results are consistent with Dong et al. (2019), following that SIC content increases with the soil depth [79]. The SIC in subsurface soil was more extensive than that in the surface layer (Figure 2b). This could be explained by the primary geological parent materials, as displayed by the $\delta^{13} \mathrm{C}_{\text {SIC }}>0$ relationship, where LIC was the primary unit of SIC in the study (Figure 5). Lettens et al. (2004) detected a strong relationship between soil geological conditions and SIC distribution [80], which is proven by our study, where SIC is positively correlated with soil pH and ESP (Figure 6). Worse soil alkali sodic status in the subsurface soil, higher $\mathrm{pH}$, and ESP (Table 1), was favorable to SIC sequestration and storage. The loose soil structure induced by tillage practice and adequate SOC content in surface soil facilitates transforming and infiltrating dissolved carbonates (DIC) [81]. Natural rainfall and irrigation promote the dissolved carbonates that originally exist in the surface soil, flowing and moving downstream, re-precipitating in deeper soil [82].

Long-term cultivation decreased SIC content in both layers in the cornfields and paddies (Figure 2b), which is in line with Wu et al. (2009), who observed SIC loss in the east of China [83]. Changes in the soil environment induced by fertilization, tillage practice, and irrigation affect SIC stocking. Dong et al. (2017) and Eshel et al. (2007) noted that cultivation practices decrease SIC, where cultivation practice disturbs calciferous soils and transports SIC into rivers and lakes, deeper soils, and groundwater through irrigation and rainfall [4,84]. Ma et al. (2013) and Zamanian et al. (2016) argued the improvement in soil sodic and alkali conditions after long-term crop cultivation has triggered SIC loss [32,85]. High contents of soil cations and salt, coupled with the alkaline environment, are harmful to decomposing carbonates but conducive to SIC sequestration [86,87]. In our study, SIC was significantly positively related to $\mathrm{pH}$ and ESP (Figure 6), so long-term cultivation hastens SIC loss for the low alkali conditions. Besides, Bai et al. (2017) declared that SIC leaching is a vital factor controlling SIC sequestration and fixation [88]; thus, the leaching of DIC may be assigned to the SIC loss with cultivation years in both layers $(0-40 \mathrm{~cm})$.

\subsection{The Effects of Crop Types on Soil C Stocks}

Total $C$ stocks varied with cultivation years, where they significantly decreased in cornfields while they upheld a stock of $120 \mathrm{Mg} \mathrm{ha}^{-1}$ in paddies (Figure 3), implying that corn and rice cultivation was disadvantageous to $C$ sequestration and storage in the study area. SOC stocks $(0-40 \mathrm{~cm})$ increased with cultivation years in both crop types, inferring that both corn and rice cultivation are beneficial to SOC sequestration. Crop cultivation lowers soil alkali sodic conditions, improving crop growth and improving soil microbial activity, thus promoting carbon transformation and sequestration in soil [89]. Liu et al. (2019) argued that rice cultivation generates more SOC than in cornfields [12]. Likewise, more massive SOC stocks were observed in paddies than cornfields in our study (Figure 3), owing to the continuous flooding irrigation practice, where the anaerobic conditions limit soil mineralization and soil organic matter decomposition, raising C stores [3,90]. SIC stocks $(0-40 \mathrm{~cm})$ decreased with increasing cultivation years, while the SIC stocks in paddies were larger than in cornfields (Figure 3). The groundwater in the arid and semiarid region contained high concentrations of the $\mathrm{Ca}^{2+}$ and $\mathrm{Mg}^{2+}$ cations [91], which hasten the formation of PIC [92]. Rice flooding irrigation dissolves soluble ions into the water, accelerating the carbonate weathering and erosion, as proven by the lower ${ }^{13} \mathrm{C}_{\text {SIC }}$ values in paddies (Figure 5). Higher silt and clay content and the larger BD in paddies (Table 1) restricted the 
infiltration of DIC, thus reducing SIC loss in paddies. Surface and subsurface soils $(0-40 \mathrm{~cm})$ are the most sensitive soil layers that are directly or indirectly disturbed by crop cultivation and tillage practice, like ploughing, fertilization, and irrigation. In our study, total C stock losses at the depth of $40 \mathrm{~cm}$ in the alkali sodic cornfields and paddies were detected. Advanced studies could consider deeper soil layers to assess the "carbon source" (or "carbon sink") function of alkali sodic agricultural soils.

\section{Conclusions}

Corn and rice cultivation improved soil alkali sodic conditions by lowering soil $\mathrm{pH}, \mathrm{EC}$, and ESP, thus increasing enzyme activities (amylase, invertase, and catalase). SOC and its stocks were negative correlated with soil pH and ESP, while SIC showed significant correlations with $\mathrm{pH}$ and ESP. Obvious positive relationships between $\mathrm{SOC}$ and enzyme activities were detected in the redundancy analysis carried out in this study. SOC, $\delta^{13} \mathrm{C}_{\mathrm{SOC}}$, and SOC stocks increased with cultivation years, while SIC, $\delta^{13} \mathrm{C}_{\mathrm{SIC}}$, and SIC stocks decreased with increasing cultivation years. A total carbon stock loss was observed in the cornfields with increasing cultivation years, while, in paddies, the stocks remained steady at $120 \mathrm{Mg} \mathrm{ha}^{-1}$. Corn and rice cultivation in the studied alkali sodic region was advantageous to improve soil alkali sodic conditions but disadvantageous to soil total carbon storage at the depth of $0-40 \mathrm{~cm}$.

Author Contributions: J.W. and W.Y. drafted the manuscript; J.T. and Z.L. designed the experiments; J.W., P.Y., and Y.Q. collected and tested the samples. All authors have read and agreed to the published version of the manuscript.

Funding: This study was supported by the National Natural Science Foundation of China (No. 41471152).

Conflicts of Interest: The authors declare no conflict of interest.

\section{References}

1. Zhang, H.; Tang, J.; Liang, S.; Li, Z.; Yang, P.; Wang, J. The Emissions of Carbon Dioxide, Methane, and Nitrous Oxide during Winter without Cultivation in Local Saline-Alkali Rice and Maize Fields in Northeast China. Sustainability 2017, 9, 1916. [CrossRef]

2. Smith, P.; Martino, D.; Cai, Z.; Gwary, D.; Janzen, H.; Kumar, P.; McCarl, B.; Ogle, S.; O’Mara, F.; Rice, C.; et al. Greenhouse gas mitigation in agriculture. Philos. Trans. R. Soc. B Biol. Sci. 2008, 363, 789-813. [CrossRef] [PubMed]

3. Kimura, M.; Murase, J.; Lu, Y. Carbon cycling in rice field ecosystems in the context of input, decomposition and translocation of organic materials and the fates of their end products $\left(\mathrm{CO}_{2}\right.$ and $\left.\mathrm{CH}_{4}\right)$. Soil Biol. Biochem. 2004, 36, 1399-1416. [CrossRef]

4. Hao, M.; Hu, H.; Liu, Z.; Dong, Q.; Sun, K.; Feng, Y.; Li, G. Shifts in microbial community and carbon sequestration in farmland soil under long-term conservation tillage and straw returning. Appl. Soil Ecol. 2019, 136, 43-54. [CrossRef]

5. Poirier, V.; Roumet, C.; Munson, A.D. The root of the matter: Linking root traits and soil organic matter stabilization processes. Soil Biol. Biochem. 2018, 120, 246-259. [CrossRef]

6. Kögel-Knabner, I.; Amelung, W.; Cao, Z.; Fiedler, S.; Frenzel, P.; Jahn, R.; Kalbitz, K.; Kölbl, A.; Schloter, M. Biogeochemistry of paddy soils. Geoderma 2010, 157, 1-14. [CrossRef]

7. Li, Q.; Zhang, X.; Gao, J.; Song, M.; Liang, J.; Yue, Y. Effects of N Addition Frequency and Quantity on Hydrocotyle vulgaris Growth and Greenhouse Gas Emissions from Wetland Microcosms. Sustainability 2019, 11, 1520. [CrossRef]

8. Wei, X.; Zhu, Z.; Wei, L.; Wu, J.; Ge, T. Rhizosphere Biogeochemical cycles of key elements in the paddy-rice rhizosphere: Microbial mechanisms and coupling processes. Rhizosphere 2019, 10, 100145. [CrossRef]

9. Wichern, F.; Mayer, J.; Joergensen, R.G.; Muller, T. Rhizodeposition of $\mathrm{C}$ and $\mathrm{N}$ in peas and oats after ${ }^{13} \mathrm{C}-{ }^{15} \mathrm{~N}$ double labbling under field condition. Soil Biol. Biochem. 2007, 39, 2527-2537. [CrossRef]

10. Kuzyakov, Y.; Domanski, G. Carbon input by plants into the soil. Review. Soil Sci. Plant Nutr. 2000, 163, 421-431. [CrossRef] 
11. Müller, K.; Kramer, S.; Haslwimmer, H.; Marhan, S.; Scheunemann, N.; Butensch, O.; Stefan, S.; Kandeler, E. Carbon transfer from maize roots and litter into bacteria and fungi depends on soil depth and time. Soil Biol. Biochem. 2016, 93, 79-89. [CrossRef]

12. Liu, Y.; Ge, T.; Zhu, Z.; Liu, S.; Luo, Y.; Li, Y.; Wang, P.; Gavrichkova, O.; Xu, X.; Wang, J.; et al. Carbon input and allocation by rice into paddy soils: A review. Soil Biol. Biochem. 2019, 133, 97-107. [CrossRef]

13. Xu, S.; Shi, X.; Zhao, Y.; Yu, D.; Li, C.; Wang, S.; Tan, M.; Sun, W. Carbon sequestration potential of recommended management practices for paddy soils of China, 1980-2050. Geoderma 2011, 166, 206-213. [CrossRef]

14. Eswaran, H.; Van den Berg, E.; Reich, P.F.; Kimble, J.M. Global soil C resources. In Soils and Globle Change; Lal, R., Kimble, J.M., Levine, E., Stewart, B.A., Eds.; CRC/Lewis Publishers: Boca Raton, FL, USA, 1995; pp. 27-44.

15. Batjes, N.H. Total carbon and nitrogen in the soils of the world. Eur. J. Soil Sci. 1996, 47, 151-163. [CrossRef]

16. Groshans, G.R.; Mikhailova, E.A.; Post, C.J.; Schlautman, M.A. Accounting for soil inorganic carbon in the ecosystem services framework for United Nations sustainable development goals. Geoderma 2018, 324, 37-46. [CrossRef]

17. Bughio, M.A.; Wang, P.; Meng, F.; Qing, C.; Kuzyakov, Y.; Wang, X.; Junejo, S.A. Neoformation of pedogenic carbonates by irrigation and fertilization and their contribution to carbon sequestration in soil. Geoderma 2016, 262, 12-19. [CrossRef]

18. West, L.T.; Drees, L.R.; Wilding, L.P.; Rabenhorst, M.C. Differentiation of pedogenic and lithogenic carbonate forms in Texas. Geoderma 1988, 43, 271-287. [CrossRef]

19. Smith, P. Global climate change and pedogenic carbonates: Edited by R. Lal, J.M. Kimble, H. Eswaran and B.A. Stewart. CRC Press, 2000. Hardbound, 305 pp. ISBN 566704588. GBP47. Geoderma 2001, 104, 180-182. [CrossRef]

20. Ding, C.; Du, S.; Ma, Y.; Li, X.; Zhang, T.; Wang, X. Changes in the $\mathrm{pH}$ of paddy soils after flooding and drainage: Modeling and validation. Geoderma 2019, 337, 511-513. [CrossRef]

21. Schoninger, E.L.; Gatiboni, L.C.; Ernani, P.R. Rhizosphere $\mathrm{pH}$ and phosphorus forms in an Oxisol cultivated with soybean, brachiaria grass, millet and sorghum. Sci. Agric. 2012, 69, 259-264. [CrossRef]

22. Jaiyeoba, I.A. Changes in soil properties due to continuous cultivation in Nigerian semiarid Savannah. Soil Tillage Res. 2003, 70, 91-98. [CrossRef]

23. Reddy, M.M. Calcite growth-rate inhibition by fulvic acid and magnesium ion-Possible influence on biogenic calcite formation. J. Cryst. Growth 2012, 352, 151-154. [CrossRef]

24. Fang, K.; Kou, D.; Wang, G.; Chen, L.; Ding, J.; Li, F.; Yang, G.; Qin, S.; Zhang, Q.; Yang, Y. Decreased soil cation exchange capacity across northern China's Grasslands over the last three decades. J. Geophys. Res. Biogeosciences 2017, 122, 3088-3097. [CrossRef]

25. Dong, X.; Hao, Q.; Li, G.; Lin, Q.; Zhao, X. Contrast effect of long-term fertilization on SOC and SIC stocks and distribution in different soil particle-size fractions. J. Soils Sediments 2017, 17, 1054-1063. [CrossRef]

26. Wang, R.; Dungait, J.A.J.; Creamer, C.A.; Cai, J.; Bo, L.; Xu, Z.; Zhang, Y.; Ma, Y.; Yong, J. Carbon and Nitrogen Dynamics in Soil Aggregates under Long-Term Nitrogen and Water Addition in a Temperate Steppe. Soil Sci. Soc. Am. J. 2015, 79, 527. [CrossRef]

27. Liu, W.; Qiao, C.; Yang, S.; Bai, W.; Liu, L. Microbial carbon use efficiency and priming effect regulate soil carbon storage under nitrogen deposition by slowing soil organic matter decomposition. Geoderma 2018, 332, 37-44. [CrossRef]

28. Bai, E.; Boutton, T.W.; Liu, F.; Wu, X.B.; Hallmark, C.T.; Archer, S.R. Spatial variation of soil $\delta^{13} \mathrm{C}$ and its relation to carbon input and soil texture in a subtropical lowland woodland. Soil Biol. Biochem. 2012, 44, 102-112. [CrossRef]

29. Bowling, D.R.; Pataki, D.E.; Randerson, J.T. Carbon isotopes in terrestrial ecosystem pools and $\mathrm{CO}_{2}$ fluxes. New Phytol. 2008, 178, 24-40. [CrossRef]

30. Chen, S.; Arrouays, D.; Angers, D.A.; Martin, M.P.; Walter, C. Soil carbon stocks under different land uses and the applicability of the soil carbon saturation concept. Soil Tillage Res. 2019, 188, 53-58. [CrossRef]

31. Chen, J.; Heiling, M.; Resch, C.; Mbaye, M.; Gruber, R.; Dercon, G. Does maize and legume crop residue mulch matter in soil organic carbon sequestration? Agric. Ecosyst. Environ. 2018, 265, 123-131. [CrossRef]

32. Zamanian, K.; Pustovoytov, K.; Kuzyakov, Y. Cation exchange retards shell carbonate recrystallization: Consequences for dating and paleoenvironmental reconstructions. Catena 2016, 142, 134-138. [CrossRef] 
33. Jin, Z.; Dong, Y.; Wang, Y.; Wei, X.; Wang, Y.; Cui, B.; Zhou, W. Natural vegetation restoration is more beneficial to soil surface organic and inorganic carbon sequestration than tree plantation on the Loess Plateau of China. Sci. Total Environ. 2014, 485-486, 615-623. [CrossRef] [PubMed]

34. An, H.; Li, Q.L.; Yan, X.; Wu, X.Z.; Liu, R.T.; Fang, Y. Desertification control on soil inorganic and organic carbon accumulation in the topsoil of desert grassland in Ningxia, northwest China. Ecol. Eng. 2019, 127, 348-355. [CrossRef]

35. Ladeiro, B. Saline Agriculture in the 21st Century: Using Salt Contaminated Resources to Cope Food Requirements. J. Bot. 2012, 2012, 310705. [CrossRef]

36. Andronov, E.E.; Petrova, S.N.; Pinaev, A.G.; Pershina, E.V.; Akhmedenov, K.M.; Gorobets, A.V. Analysis of the Structure of Microbial Community in Soils with Different degrees of Salinization Using T RFLP and Real Time PCR Techniques. Soil Biol. 2012, 45, 147-148. [CrossRef]

37. Pan, C.; Liu, C.; Zhao, H.; Wang, Y. Changes of soil physico-chemical properties and enzyme activities in relation to grassland salinization. Eur. J. Soil Biol. 2013, 55, 13-19. [CrossRef]

38. Yan, N.; Marschner, P.; Cao, W.; Zuo, C.; Qin, W. Influence of salinity and water content on soil microorganisms. Int. Soil Water Conserv. Res. 2015, 3, 316-323. [CrossRef]

39. Ananyeva, K.; Wang, W.; Smucker, A.J.M.; Rivers, M.L.; Kravchenko, A.N. Can intra-aggregate pore structures affect the aggregate's effectiveness in protecting carbon? Soil Biol. Biochem. 2013, 57, 868-875. [CrossRef]

40. Dianwei, L.; Zongming, W.; Kaishan, S.; Bai, Z.; Liangjun, H.; Ni, H.; Sumei, Z.; Ling, L.; Chunhua, Z.; Guangjia, J. Land use/cover changes and environmental consequences in Songnen Plain, Northeast China. Chin. Geogr. Sci. 2009, 19, 299-305.

41. IUSS Working Group WRB. World Reference Base for Soil Resources 2006, 2nd ed.; FAO: Rome, Italy, 2006; p. 103.

42. Tang, J.; Wang, J.; Li, Z.; Wang, S.; Qu, Y. Effects of Irrigation Regime and Nitrogen Fertilizer Management on $\mathrm{CH}_{4}, \mathrm{~N}_{2} \mathrm{O}$, and $\mathrm{CO}_{2}$ Emissions from Saline-Alkaline Paddy Fields in Northeast China. Sustainability 2018, 10, 475. [CrossRef]

43. Wei, J.; Cheng, J.; Li, W.; Liu, W. Comparing the effect of naturally restored forest and grassland on carbon sequestration and its vertical distribution in the Chinese Loess Plateau. PLoS ONE 2012, 7, e40123. [CrossRef]

44. Wu, F.; Zhao, Y.; Fang, X.; Meng, Q. An ecological response to the Eocene / Oligocene transition revealed by the $813 C$ TOC record, Lanzhou Basin, NE Tibetan Plateau. J. Asian Earth Sci. 2018, 159, 74-80. [CrossRef]

45. Zhang, C.; Liu, G.; Xue, S.; Song, Z. Rhizosphere soil microbial activity under different vegetation types on the Loess Plateau, China. Geoderma 2011, 161, 115-125. [CrossRef]

46. Zhang, P.; Tang, J.; Sun, W.; Yu, Y.; Zhang, W. Differential effects of conservational management on SOC accumulation in the grasslands of China. PLOS ONE 2015, 10, 1-15. [CrossRef] [PubMed]

47. Parihar, C.M.; Yadav, M.R.; Jat, S.L.; Singh, A.K.; Kumar, B.; Pradhan, S.; Chakraborty, D.; Jat, M.L.; Jat, R.K.; Saharawat, Y.S.; et al. Long term effect of conservation agriculture in maize rotations on total organic carbon, physical and biological properties of a sandy loam soil in north-western Indo-Gangetic Plains. Soil Tillage Res. 2016, 161, 116-128. [CrossRef]

48. Bai, Z.; Caspari, T.; Gonzalez, M.R.; Batjes, N.H.; Mäder, P.; Bünemann, E.K.; de Goede, R.; Brussaard, L.; $\mathrm{Xu}$, M.; Ferreira, C.S.S.; et al. Effects of agricultural management practices on soil quality: A review of long-term experiments for Europe and China. Agric. Ecosyst. Environ. 2018, 265, 1-7. [CrossRef]

49. Luo, S.; Tian, L.; Chang, C.; Wang, S.; Zhang, J.; Zhou, X.; Li, X.; Tran, L.S.P.; Tian, C. Grass and maize vegetation systems restore saline-sodic soils in the Songnen Plain of northeast China. Land Degrad. Dev. 2018, 29, 1107-1119. [CrossRef]

50. Wang, Y.; Wang, Z.L.; Feng, X.; Guo, C.; Chen, Q. Long-term effect of agricultural reclamation on soil chemical properties of a coastal saline marsh in Bohai Rim, Northern China. PLoS ONE 2014, 9, 1-7. [CrossRef]

51. Awe, G.O.; Reichert, J.M.; Fontanela, E. Sugarcane production in the subtropics: Seasonal changes in soil properties and crop yield in no-tillage, inverting and minimum tillage. Soil Tillage Res. 2020, 196, 104447. [CrossRef]

52. McVay, K.A.; Budde, J.A.; Fabrizzi, K.; Mikha, M.M.; Rice, C.W.; Schlegel, A.J.; Peterson, D.E.; Sweeney, D.W.; Thompson, C. Management effects on soil physical properties in long-term tillage studies in Kansas. Soil Sci. Soc. Am. J. 2006, 70, 434-438. [CrossRef]

53. Zhang, Y.L.; Chen, L.J.; Chen, X.H.; Tan, M.L.; Duan, Z.H.; Wu, Z.J.; Li, X.J.; Fan, X.H. Response of soil enzyme activity to long-term restoration of desertified land. Catena 2015, 133, 64-70. [CrossRef] 
54. Jian, S.; Li, J.; Chen, J.; Wang, G.; Mayes, M.A.; Dzantor, K.E.; Hui, D.; Luo, Y. Soil extracellular enzyme activities, soil carbon and nitrogen storage under nitrogen fertilization: A meta-analysis. Soil Biol. Biochem. 2016, 101, 32-43. [CrossRef]

55. Katsalirou, E.; Deng, S.; Nofziger, D.L.; Gerakis, A. Long-term management effects on organic C and N pools and activities of C-transforming enzymes in prairie soils. Eur. J. Soil Biol. 2010, 46, 335-341. [CrossRef]

56. Akhtar, K.; Wang, W.; Ren, G.; Khan, A.; Feng, Y.; Yang, G. Changes in soil enzymes, soil properties, and maize crop productivity under wheat straw mulching in Guanzhong, China. Soil Tillage Res. 2018, 182, 94-102. [CrossRef]

57. Teng, M.; Zeng, L.; Xiao, W.; Huang, Z.; Zhou, Z.; Yan, Z.G.; Wang, P. Spatial variability of soil organic carbon in Three Gorges Reservoir area, China. Sci. Total Environ. 2017, 599-600, 1308-1316. [CrossRef]

58. Liu, X.; Zhang, X.; Chen, S.; Sun, H.; Shao, L. Subsoil compaction and irrigation regimes affect the root-shoot relation and grain yield of winter wheat. Agric. Water Manag. 2015, 154, 59-67. [CrossRef]

59. Rostamza, M.; Richards, R.A.; Watt, M. Response of millet and sorghum to a varying water supply around the primary and nodal roots. Ann. Bot. 2013, 112, 439-446. [CrossRef]

60. Lu, M.; Zhou, X.H.; Luo, Y.; Fang, C.M.; Chen, J.K.; Li, B. Minor stimulation of soil carbon storage by nitrogen addition: A meta-analysis. Agric. Ecosyst. Environ. 2011, 140, 234-244. [CrossRef]

61. Wang, X.J.; Xu, M.G.; Wang, J.P.; Zhang, W.J.; Yang, X.Y.; Huang, S.M.; Liu, H. Fertilization enhancing carbon sequestration as carbonate in arid cropland: Assessments of long-term experiments in northern China. Plant Soil 2014, 380, 89-100. [CrossRef]

62. Ai, C.; Liang, G.; Sun, J.; Wang, X.; He, P.; Zhou, W. Different roles of rhizosphere effect and long-term fertilization in the activity and community structure of ammonia oxidizers in a calcareous fluvo-aquic soil. Soil Biol. Biochem. 2013, 57, 30-42. [CrossRef]

63. Paungfoo-lonhienne, C.; Yeoh, Y.K.; Kasinadhuni, N.R.P.; Lonhienne, T.G.A.; Robinson, N.; Hugenholtz, P.; Ragan, M.A.; Schmidt, S. Nitrogen fertilizer dose alters fungal communities in sugarcane soil and rhizosphere. Sci. Rep. 2015, 5, 8678. [CrossRef] [PubMed]

64. Pavan Fernandes, S.A.; Bettiol, W.; Cerri, C.C. Effect of sewage sludge on microbial biomass, basal respiration, metabolic quotient and soil enzymatic activity. Appl. Soil Ecol. 2005, 30, 65-77. [CrossRef]

65. Gerzabek, M.H.; Haberhauer, G.; Kirchmann, H. Soil Organic Matter Pools and Carbon-13 Natural Abundances in Particle-Size Fractions of a Long-Term Agricultural Field Experiment Receiving Organic Amendments. Soil Sci. Soc. Am. J. 2001, 352-358. [CrossRef]

66. Liang, Q.; Chen, H.; Gong, Y.S.; Fan, M.S.; Yang, H.; Lal, R.; Kuzyakov, Y. Effects of 15 years of manure and inorganic fertilizers on soil organic carbon fractions in a wheat-maize system in the North China Plain. Nutr. Cycl. Agroecosystems 2012, 92, 21-33. [CrossRef]

67. Paul, E.A. The nature and dynamics of soil organic matter: Plant inputs, microbial transformations, and organic matter stabilization. Soil Biol. Biochem. 2016, 98, 109-126. [CrossRef]

68. Solly, E.F.; Schöning, I.; Herold, N.; Trumbore, S.E.; Schrumpf, M. No depth-dependence of fine root litter decomposition in temperate beech forest soils. Plant Soil 2015, 393, 273-282. [CrossRef]

69. Steinweg, J.M.; Kostka, J.E.; Hanson, P.J.; Schadt, C.W. Temperature sensitivity of extracellular enzymes differs with peat depth but not with season in an ombrotrophic bog. Soil Biol. Biochem. 2018, 125, 244-250. [CrossRef]

70. Frankenberger, W.T.; Johanson, J.B. Effect of $\mathrm{pH}$ on enzyme stability in soils. Soil Biol. Biochem. 1982, 14, 433-437. [CrossRef]

71. Hartman, W.H.; Richardson, C.J.; Vilgalys, R.; Bruland, G.L. Environmental and anthropogenic controls over bacterial communities in wetland soils. Proc. Natl. Acad. Sci. USA 2008, 1-6. [CrossRef]

72. Andersen, R.; Chapman, S.J.; Artz, R.R.E. Microbial communities in natural and disturbed peatlands: A review. Soil Biol. Biochem. 2013, 57, 979-994. [CrossRef]

73. Wang, Y.; Jiang, J.; Niu, Z.; Li, Y.; Li, C.; Feng, W. Responses of soil organic and inorganic carbon vary at different soil depths after long-term agricultural cultivation in Northwest China. L. Degrad. Dev. 2019, 30, 1229-1242. [CrossRef]

74. Du, H.; Wang, T.; Xue, X.; Li, S. Estimation of soil organic carbon, nitrogen, and phosphorus losses induced by wind erosion in Northern China. Land Degrad. Dev. 2019, 30, 1006-1022. [CrossRef]

75. Abdalla, K.; Mutema, M.; Chivenge, P.; Everson, C.; Chaplot, V. Grassland degradation significantly enhances soil $\mathrm{CO}_{2}$ emission. Catena 2018, 167, 284-292. [CrossRef] 
76. Huang, L.; Hu, W.; Tao, J.; Liu, Y.; Kong, Z.; Wu, L. Soil bacterial community structure and extracellular enzyme activities under different land use types in a long-term reclaimed wetland. J. Soils Sediments 2019, 19, 2543-2557. [CrossRef]

77. Zhang, C.; Liu, G.; Xue, S.; Wang, G. Soil bacterial community dynamics reflect changes in plant community and soil properties during the secondary succession of abandoned farmland in the Loess Plateau. Soil Biol. Biochem. 2016, 97, 40-49. [CrossRef]

78. Rani, J.; Pal, B.; Cowie, A.L.; Fang, Y.; Collins, D.; Dougherty, W.J.; Singh, B.K. Carbon and nutrient mineralisation dynamics in aggregate-size classes from different tillage systems after input of canola and wheat residues. Soil Biol. Biochem. 2018, 116, 22-38.

79. Dong, X.; Singh, B.P.; Li, G.; Lin, Q.; Zhao, X. Biochar increased field soil inorganic carbon content five years after application. Soil Tillage Res. 2019, 186, 36-41. [CrossRef]

80. Lettens, S.; Van Orshoven, J.; van Wesemael, B.; Muys, B. Soil organic and inorganic carbon contents of landscape units in Belgium derived using data from 1950 to 1970. Soil Use Manag. 2004, 20, 40-47. [CrossRef]

81. Lal, R. Soil carbon sequestration impacts on global climate change and food security. Science 2004, 304, 1623-1627. [CrossRef]

82. Khokhlova, O.S.; Arlashina, E.A.; Kovalevskaya, I.S. The effect of irrigation on the carbonate status of Chernozems of Central Precaucasus (Russia). Soil Technol. 1997, 11, 171-184. [CrossRef]

83. Wu, H.; Guo, Z.; Gao, Q.; Peng, C. Distribution of soil inorganic carbon storage and its changes due to agricultural land use activity in China. Agric. Ecosyst. Environ. 2009, 129, 413-421. [CrossRef]

84. Eshel, G.; Fine, P.; Singer, M.J. Total Soil Carbon and Water Quality: An Implication for Carbon Sequestration. Soil Sci. Soc. Am. J. Abstract 2007, 71, 397-405. [CrossRef]

85. Ma, J.; Wang, Z.; Stevenson, B.A.; Zheng, X.; Li, Y. An inorganic $\mathrm{CO}_{2}$ diffusion and dissolution process explains negative CO2 fluxes in saline/alkaline soils. Sci. Rep. 2013, 3, 2025. [CrossRef] [PubMed]

86. Xie, J.; Li, Y.; Zhai, C.; Li, C.; Lan, Z. $\mathrm{CO}_{2}$ absorption by alkaline soils and its implication to the global carbon cycle. Environ. Geol. 2009, 56, 953-961. [CrossRef]

87. Zhao, X.; Zhao, C.; Wang, J.; Stahr, K.; Kuzyakov, Y. $\mathrm{CaCO}_{3}$ recrystallization in saline and alkaline soils. Geoderma 2016, 282, 1-8. [CrossRef]

88. Bai, S.G.; Jiao, Y.; Yang, W.Z.; Gu, P.; Yang, J.; Liu, L.J. Review of progress in soil inorganic carbon research. IOP Conf. Ser. Earth Environ. Sci. 2017, 100, 012129. [CrossRef]

89. Liu, Y.; Ge, T.; Ye, J.; Liu, S.; Shibistova, O.; Wang, P.; Wang, J.; Li, Y.; Guggenberger, G.; Kuzyakov, Y.; et al. Initial utilization of rhizodeposits with rice growth in paddy soils: Rhizosphere and $\mathrm{N}$ fertilization effects. Geoderma 2019, 338, 30-39. [CrossRef]

90. Qiu, H.; Ge, T.; Liu, J.; Chen, X.; Hu, Y.; Wu, J.; Su, Y.; Kuzyakov, Y. Effects of biotic and abiotic factors on soil organic matter mineralization: Experiments and structural modeling analysis. Eur. J. Soil Biol. 2018, 84, 27-34. [CrossRef]

91. An, H.; Wu, X.; Zhang, Y.; Tang, Z. Effects of land-use change on soil inorganic carbon: A meta-analysis. Geoderma 2019, 353, 273-282. [CrossRef]

92. Sanderman, J. Can management induced changes in the carbonate system drive soil carbon sequestration? A review with particular focus on Australia. Agric. Ecosyst. Environ. 2012, 155, 70-77. [CrossRef]

(C) 2020 by the authors. Licensee MDPI, Basel, Switzerland. This article is an open access article distributed under the terms and conditions of the Creative Commons Attribution (CC BY) license (http://creativecommons.org/licenses/by/4.0/). 